\title{
The Organization of Personal Pronouns in Sentence Structure Construction of Makassarese Language
}

\author{
Asriani Abbas \\ Faculty of Humanities, Hasanuddin University, Makassar, Indonesia \\ Kaharuddin \\ Faculty of Humanities, Hasanuddin University, Makassar, Indonesia \\ Muhammad Hasyim \\ Faculty of Humanities, Hasanuddin University, Makassar, Indonesia
}

\begin{abstract}
Makassarese language belongs to the Austronesian language family, currently spoken as a mother language by a group of people in South Sulawesi province, eastern Indonesia. This research focuses on personal pronoun organization in the sentence construction of the Makassarese language. The form, position, and function of personal pronouns in the language sentences are explained. It used 'simak' (to-observe) method in form of a conversational involved-observation technique including recording and note-taking in collecting data. The data sources were oral data and text data. The oral data were taken from five informants selected purposively. The text data were taken from the folklore script of South Sulawesi written in the Makassarese language. The data were presented descriptively and analyzed by using the distributional method. The findings show two forms of personal pronouns used dominantly in constructing sentences: free personal pronoun and bound personal pronoun (clitic). Position of the free personal pronoun is in front of, in the middle of, and at the end of a sentence. The clitic is in front of and at the end of the verb. In addition, there is also clitic attached at the end of the noun that serves as possessive. The sentence starting with a free personal pronoun forms the pattern of SV (subject-verb) or SVO (subject-verb-object) and the sentence starting with clitic-attached verb forms the pattern of VS (verb-subject) or VSO (verb-subject-object). The basic structure of the Makassarese sentence is VS or VSO. The derivative structure is SV or SVO with other varieties.
\end{abstract}

Index Terms-Makassarese language, free personal pronoun, clitic

\section{INTRODUCTION}

Makassarese language is one of the hundreds of local languages in Indonesia, originated from an Austronesian language family and spoken as a mother language by a group of people in the South Sulawesi province of eastern Indonesia. The Language Map of South Sulawesi points to the southern part of South Sulawesi Peninsula as the area where the Makassarese language is mainly spoken encompassing Gowa, Takalar, Jeneponto, Bantaeng, Selayar, some parts of Bulukkumba, Maros, Pangkajene Islands and Makassar. Some local dialect varieties are the Lakiung dialect, Turatea dialect, Bantaeng dialect, Konjo dialect, and Bira-Selayar dialect.

Lakiung dialect is chosen as the object of this research. The dialect is spoken by people living in Makassar city, western Gowa Regency, and Takalar Regency. The name of Lakiung was taken from the name of a place in Gowa serving as the centre of governance during the glory days of the Gowa Kingdom. Lakiung dialect is considered a standard dialect of the Makassarese language. Makassarese language was historically the official language in the Gowa Kingdom and is presently taught at schools as 'Muatan Lokal' (Local Content) education (Basang and Arif, 1981; Karim et al., 2019).

The Indonesian government has sought about preserving the regional ethnic languages since 1995 by including them in the 'local content' curriculum in Primary and Secondary Schools. However, ethnic language learning is currently still in problems of the inadequacy of learning materials and unavailability of competent teachers. It needs more tenacious creative researches to make the dissemination of ethnic language awareness successful. This language must be sustained to reach the future generation and therefore current observers, researchers, teachers, and learners are obliged to protect the language from extinction.

This paper discusses how to organize personal pronouns in Makassarese sentences, both the free personal pronoun and the bound personal pronoun (clitic) and exposes linguistic rules in constructing sentences grammatically. This paper can be an important document as guidance for observers, researchers, teachers, and learners of the Makassarese language in composing sentences and distinguishing the basic structure from the derivative structure in the language. 


\section{PERSONAL PRONOUN}

Universally, Austronesian languages highlight the importance of personal pronouns in grammatical relations. The language of Bukindo Manobo Barat as one of the Filipino languages for example considered the role of personal pronoun vital in determining syntactic relations, especially in focus-purpose constructions. Structuring the personal pronoun marker largely determines the relationship between verbs and other elements in sentence construction. Payne (1997) stated three formal characteristics of grammatical relations: (1) case marker, (2) marking reference of the participant to verbs, and (3) constituent ordering. A similar function is equally visible in Tagalog and Chamorro as well as Northern Subuanen (Elkins and Marten in Ibrahim, 2002).

The local languages in Indonesia are found to have one common characteristic, namely a three type division of personal pronouns based on function. Each type of pronoun has its reference function, such as referring to oneself (firstperson pronoun), referring to the person to whom the first person speaks (second-person pronoun) or referring to the person in question (third-person pronoun). The pronouns can be free or bound (clitic).

\section{A. Clitics}

The term clitic is originated from the Greek word klinien meaning 'to lean'. It refers to a morpheme attached to basic units (words). Verhaar (1978) and Ramlan (1985) refer to the Indonesian pronouns positioned in front of the verb as proclitics such as ' $k u^{-}$' in 'kuambil' and ' $k a u-$ ' in ' $k a u a m b i l$ '. Whereas the pronouns attached at the end of the verb are called enclitic such as '-ku' in 'bukuku', '-mu' in 'bukumu', and '-nya' in 'bukunya'. These pronouns serve as a possessive marker. In addition, there is also ' $-k a h$ ', and '-lah' denoting affirmation and command. Overall, these forms are called clitic. Clitic in Makassarese, similar to Indonesian and Buginese counterparts, mainly consists of the shortened form of free personal pronouns.

Makassarese language has free personal pronouns, such as 'nakké (I/me), a singular first-person pronoun and ' $k a t t e ́$ ' ( we/us), a plural first-person pronoun. Both can be either exclusive or inclusive. 'Kau' and 'Katte' (you) are respectively familiar and honorific. Both are singular second-person pronouns. 'Kaungaséng' and 'katténgaséng' (plural of you) are also respectively familiar and honorific, both are plural second-person pronouns. Lastly, there is ' $\mathrm{i} a$ ' (she/he) as the singular third-person pronoun and 'iangaséng ' (they) as the plural third-person pronoun.

TABLE 1.

PERSONAL PRONOUN IN MAKASSARESE LANGUAGE

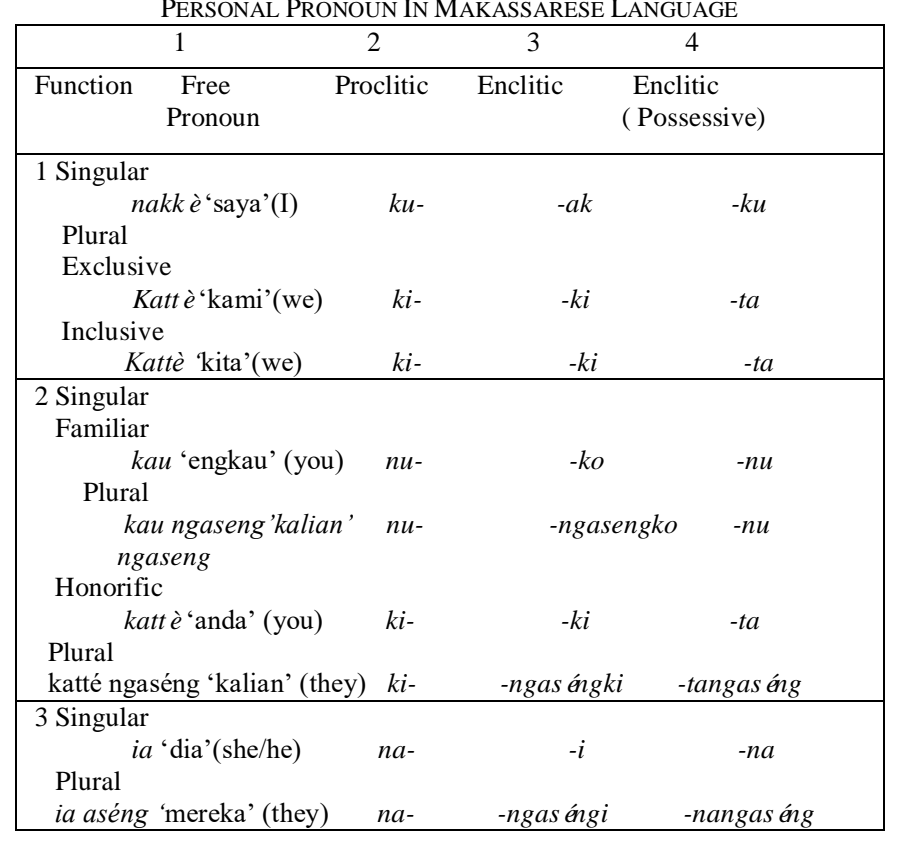

\section{B. Sentence Structure}

The basic structure of sentences that neutrally works in each language is called by Dixon (1994) as the underlying structure. It is the original structure in a language that has not undergone any modification or derivation, neither related to morphological derivation nor syntactic derivation. This concept of default structure is identically shared by the basic sentence of every language in the world. Nonetheless, some languages have the same type of structure, and some others are different. The type of sentence structure will give a clear picture of the typology of a language. The depiction of sentence structure types was once performed by Lehmann (1978, p.35). The expert grouped the world's languages into three types:

(1) the consistent type in which object precedes the verb (OV);

(2) the consistent type in which the verb precedes the object (VO); and 
(3) inconsistent type in which the object precedes the verb (OV) or the verb precedes the object (VO).

The view of Lehmann (1978) was applied by Comrie through Turkish and Russian examples. According to Comrie, (1978) Turkish has a basic structure type in which the object precedes the verb (SOV), while the Russian language has more like a free structure in which the possible patterns can be (SVO), (SOV), VOS), (OSV), (OVS), and (VSO).

Turkish examples:

Hasan okuz - $u$ aldi

Hasan sapi Akusatif beli (Hasan buys a cow)

'Hasan membeli sapi' (Hasan buys a cow)

Russian examples:

Tanja membunuh Masha. (Tanja kills Masha)

The sentence can be organized in various constituent sequences:

SVO: Tanj - a ubila Mas - u

SOV: Tanj - a Mas - u - ubila

VOS: Ubila - Mas - Tanj - a

OSV: Mas - u - Tanj - a - ubila

OVS: Mas - u ubila Tanj - a

In Russian, the nominative case marker of suffix - $a$ specifies the subject function (S) and the accusative case marker $u$ determines the object function $(\mathrm{O})$. Thus, the functions of $\mathrm{S}$ and $\mathrm{O}$ are not determined by their position in the sentence but determined based on the case markers that follow. Tanja with nominative case $-a$ occupies the function $\mathrm{S}$ and the word Mashu with nominative case $-u$ occupies the object function even if placed in any position (Usman, 1995).

It seems that English and Indonesian have the same type of structure: O follows the verb as in the SVO type structure in which $\mathrm{S}$ and $\mathrm{O}$ functions are determined by the order of the sentence units.

Examples:

$$
\begin{array}{ll}
\text { English in SVO } & \text { : Mary saw John. } \\
\text { Indonesian in SVO } & : \text { Meri melihat Jon. }
\end{array}
$$

Mary and Meri occupy the S function because of its position preceding the active verbs or predicate. In contrast, John and Jon occupy the $\mathrm{O}$ function because of its position after the predicate or the active verb.

The structure of the basic sentence or the underlying (core) structure is constructed by a neutral single clause that has the characteristics of completeness, affirmative, positive, and active (Parera, 1991). In morphological derivation, any change of affixation in the basic verb alters the structure of each clause-forming element which consequently also changes the relation in arguments. The change of relations in arguments affects the meaning of the sentence. Similarly, in syntactic derivation, inter-argument relation leads to the status-transferring process. In this case, each argument experiences a change of function in a transitive event.

Examples:

John was seen by Mery.

John dilihat oleh Meri

The chnge in position of John makes a change in function. In the second example, John functions as $\mathrm{O}$ which is contrary to the previous example where John is on S. 'Was seen' is the predicate (V) and 'by Mery' is the complementary function (Alwasilah, 1983). Therefore, the existence of a variety of structures in languages all over the world can be the basis of comparison to understand the structure of Makassarese language based on personal pronoun organization with verbs as the centre of the functional structure of the sentence.

\section{Material \& Methodology}

The data is in the Makassarese language mainly in form of oral data. The source was the speech of five informants who were selected purposively. The informants lived in the Somba Opu sub-district, Gowa regency is one of the bases of Makassarese language users. They were 20-60 years old on average with a high level of proficiency in Makassarese language, be able to holistically understand how their language system works, physically be able to speak (possess a complete set of speech devices), never resided in another area for more than three months, and psychologically demonstrated a good amount of enthusiasm (cooperativeness) in providing the data corpus.

This research used 'simak' (to-observe) method in form of a conversational involved-observation technique including recording and note-taking (Rahman et al., 2019; Hasyim et al., 2021). The conversational involved-observation technique was conducted through face-to-face interviews with the question-answer session in which directed corpus stimulation was employed. Furthermore, the oral data were also equipped with text data of the script of South Sulawesi's folklore in the Makassarese language. The data were presented descriptively and analyzed using the distributional method (Hasyim, 2017).

\section{RESULTS AND DisCUSSION}

Pronunciation of Personal Pronoun in Makassarese Language 
Makassarese sentence structure may appear unique. A single sentence consists of at least two constituents which can be as verbs (V) and as subject (S). In certain situations, the object (O) comes after the verb (VOS). In another instance, $\mathrm{O}$ comes after S (VSO). In general, the subject in the Makassarese language is located after the verb (VS). In other cases, the subject precedes the verb (SV), especially in sentences that have undergone structural variation. The structure of the Makassarese sentence is recognizable based on the organization of personal pronouns which constructs a particular sentence.

\section{A. First-Person Pronouns}

The first person pronoun (the pronoun 1) is found in free or bound form. Some free personal pronouns are singular and some others are plural. In addition, there is also a bound form called clitic, either proclitic or enclitic.

\section{Singular First Person Pronoun}

The singular first-person pronoun such as nakké (I/me) belongs to the free personal pronouns. The free personal pronoun is commonly prefixed by ' $i$ ' or ' $s i$ ' articles, such as 'inakké' in the basic sentence structure. However, if there is a variation in the sentence structure, the ' $i$ ' and 'si' articles undergo ellipsis. The singular first-person pronoun 'inakke' is neutral in that it does not reflect the social hierarchy between the addressee and addresser. The enclitic variations of the pronoun 'inakké' are $-a k^{\prime}$ and $-k u^{\prime}$ plus $-k u$ as proclitic as well. Enclitic $-a k$ and proclitic $-k u$ are attached to verbs with the subject role (agentive), whereas enclitic $-k u$ is attached to nouns as possessive.

1. The first single-person pronoun inakke 'me'

The first single-person pronoun is always located in the initial position of the sentence.

Example:

(1) Inakké ammalli bokbok.

$\begin{array}{lll}\frac{\text { i nakke }}{\text { art- P1 }} \underset{\text { pref beli (buy/bought) }}{\frac{\text { aN- balli }}{\text { buku( a book) }}} & \frac{\text { bokbok }}{\text { V }} & \text { O }\end{array}$

Saya membeli buku.' (I buy a book)

In sentence (1) the singular first-person pronoun 'inakké (English: I) is positioned at the beginning of the sentence occupying the subject function with an agentive role. The sentence organization initiated by the personal pronoun inakké follows the SVO pattern.

2. Enclitic -ak 'saya (English: I)

Enclitic -ak sticks behind the verb.

Example:

(2) Ammalliak bokbok.

$\frac{\text { aN- balli -ak }}{\text { pref beli (buy) P1encl }}$ bokbok
V buku (book)
'Membeli saya buku' (I buy a book)

In sentence (2) the enclitic - $a k$ attached at the end of the verb occupies the subject function, bearing an agentive role. The sentence organization initiated by a verb to which enclitic $-a k$ is clung follows the VSO pattern.

3. Proclitic -ku

Proclitic ' $-k u$ ’ saya (English: I) makes a definite marker - a appear.

Example:

(3) Kuballi bokboka

$\begin{array}{lc}\frac{\mathrm{ku}-\text { balli }}{\mathrm{p} 1 \text { prok beli (buy) }} & \frac{\text { bokbok -a }}{\text { buku (book) def }} \\ \mathrm{V} & \text { O }\end{array}$

'Kubeli buku itu' (I buy the book)

In sentence (3) the proclitic - $k u$ in ' $k u b a l l i$ ' necessitates the use of the definite marker -a on 'bokbok' and changes the form to 'bokboka'. In certain situation, 'bokboka' is positioned at the beginning of the sentence.

Example:

(4) Bokboka kuballi

$\frac{\text { Bokbok -a }}{\text { Buku (book) def }} \quad \frac{\text { ku- balli }}{\text { plprok beli (buy) }}$

'Buku saya beli.' ( I buy just the book)

In sentence (4), there is a different nuance in the sentence. It is because the use of marker $-a$ in this type of sentence organization produces a different meaning, 'bokboka' in this context is translated as 'only the book'. Generally, it can be omitted. The next example shows where the definite marker $-a$ is omitted (ellipsis).

Example:

(5) Bokbok kuballi

bokbok ku- balli


. Enclitic '-ku' (saya/I)

buku (book) p1proc beli (buy)

S V

' (I buy the book)

Enclitic-ku may be attached to nouns

Example:

(6) Kuboliki bokbokku

$\begin{array}{llcc}\begin{array}{l}\text { Ku- } \\ \text { p1proc }\end{array} & \begin{array}{c}\text { bolik } \\ \text { simpan (keep) }\end{array} & \begin{array}{c}-\mathrm{p} \text { 3enc boku(book) } \\ \text { V }\end{array} & \begin{array}{c}-k u \\ \text { plenc }\end{array} \\ \text { 'Saya menyimpan buku saya' (I keep my book.) }\end{array}$

In sentence (6) the enclitic $-k u$ attached to bokbok (a noun) serves as a possessive marker. The function of the possessive marker is be assumed by nakke which is the free form of the personal pronoun, It should always be the enclitic form in use. Another similar use is seen in doékku (my money).

\section{Plural First-Person Pronoun}

Makassarese language also has the plural first-person pronouns, such as 'katte' (kita/kami, English: we) in form of inclusive (kita) and exclusive (kami) plural. Such pronouns include a free personal pronoun. In the basic sentence structure, the free personal pronoun is generally preceded by the ' $i$ ' or 'si' article, such as (i) our neutral 'ikatte'(kita/kami). Its use does not reflect any social hierarchy between addresser and addressee. However, if a certain modification in the sentence structure occurs as in some variants of structure, the ' $\mathrm{i}$ ' or 'si' article undergoes an ellipsis.

The plural first-person pronoun 'ikatte' 'kita/kami' (we/us) is reduced to enclitic form $-k i$, and $-t a$, as well as prolific $k i$. All of which also denote the same reference 'kita/kami' (we/us). However, the enclitic $-k i$ changes to the prefix $n i$ - (di-). The reason is to distinguish it from proclitic $-k i$ which also denotes 'anda' (you) as a pronoun of the honorific second-person pronoun when it is used in an imperative sentence. The enclitic $-k i$ and prefix $n i$ - is attached to the verb and they possess an agentive role. Furthermore, the enclitic $-t a$ is attached to nouns with a possessive role.

1.Plural First-Person Pronoun 'ikatte'

The Plural First-Person Pronoun is always positioned at the beginning of the sentence.

Example:

(7) Ikatté ammalli bokbok

$\begin{array}{lll}\text { i katté } & \text { aN- balli } & \text { bokbok } \\ \text { art- p1j } & \text { pref beli (buy) } & \text { buku (book) } \\ \mathrm{S} & \mathrm{O} & \mathrm{O}\end{array}$

'Kita/Kami membeli buku' (We buy a book)

In the phrase (7) the plural first-person pronoun 'ikatte' is put in front of the sentence occupying the function as the subject with the agentive role. The sentence begins with the plural first-person pronoun 'ikatte' and it follows the SVO pattern.

2. Enclitic -ki

Enclitic - ki is attached behind the verbs

Example:

(8) Ammalliki bokbok

$$
\begin{array}{llc}
\text { aN- balli } & -k i & \text { bokbok } \\
\text { pref beli(buy) } & \text { p1j enc } & \text { buku(book) } \\
\mathrm{V} & \mathrm{S} & \mathrm{O} \\
\text { 'Membeli kami/kita buku'. (We buy a book) }
\end{array}
$$

In the (8) enclitic $-k i$ is attached at the end of the verb and functioning as the subject with an agentive role. The sentence in which the verb precedes the enclitic -ki follows VSO pattern.

3. Proclitic ki- or prefix ni-

Proclitic $k i$ - can be replaced by the prefix $n i$ - on daily speech. The proclitic $k i$ - or the prefix $n i$ - necessitates the definitive marker -a to appear.

Example:

(9) Niballi bokboka.

$$
\begin{array}{lllr}
\text { ni- } & \text { balli } & \text { bokbok } & \text {-a } \\
\text { p1jproc } & \text { beli(buy) } & \text { buku(book) } & \text { def } \\
\text { V } & \multicolumn{2}{c}{\text { O }} &
\end{array}
$$

Buku kami/kita beli (We buy the book.)

In certain situations, 'bokboka' can be at the beginning of the sentence.

Example:

(10) Bokboka niballi

Bokbok -a ni- balli

buku(book) def p1j proc beli (buy) 
S $\mathrm{V}$

'Buku kami/kita beli.' (We buy the book)

In Sentence (4), there is a different nuance in the sentence, because the use of marker $-a$ creates a different meaning. 'Bokboka' in this context is translated as 'only the book'. Generally, it can be omitted. The next example shows where the definite marker $-\mathrm{a}$ is omitted (ellipsis).

Example:

(11) Bokbok niballi

$$
\begin{aligned}
& \text { bokbok ni- balli } \\
& \text { buku (book) } 1 \text { j proc beli (buy) } \\
& \mathrm{S} \quad \mathrm{V} \\
& \text { 'Buku kami/kita beli. (we buy the book) }
\end{aligned}
$$

4. Enclitic -ta

Enclitic -ta can be attached to nouns

Example:

(12) Niboliki bokbotta

$\begin{array}{llcll}\begin{array}{l}\text { ni- } \\ \text { p1prok } \quad \text { bolik }\end{array} & -\mathrm{i} & \begin{array}{c}\text { bokbok } \\ \text { buku (book) }\end{array} & \text {-ta } \\ \text { p1enc }\end{array}$

Enclitic - $t a$ attached at the end of 'bokbok' to become 'bokbokta' serves as a possessive marker. The function of possessive marker - $t a$ is different from 'katte' which is the free form of the personal pronoun. Hence, 'bokbotta' is the only possible form.

It is also possible to compound the plural first-person pronoun $-k i$ with the additional marker ngaséng. Hence it becomes 'ikatténgaséng ' (All of us/ We all)

Example:

(13) Akbicak-bicarangasengki ri dallékang ballakna

$$
\begin{aligned}
& \underline{\text { ak- bicak-bicara }} \underline{\text { ngasengki }} \underline{\text { ri dallékang }} \underline{\text { ballak }} \underline{\text {-na }} \\
& \text { pref bicara bicara (having a talk) p1j.enk prep depan (in front of) rumah (house) p3enc } \\
& \mathrm{V} \quad \mathrm{S} \text { K }
\end{aligned}
$$

'Kita sedang bercakap-cakap di depan rumahnya'. ('We are having a talk in front of his house'.

However, the plural marker 'ngaséng' is not used anymore. In daily conversations, the marker can be omitted. In the case of the above example, the plural marker 'ngaséng' refers to either only some parts of reference (only some individuals in the conversation group) or the entire part of the reference (the whole individuals in the group). To know the participants in the conversation, looking at the contextual cue is necessary.

Example:

(14) Akbicak-bicaraki ri dallékang ballakna

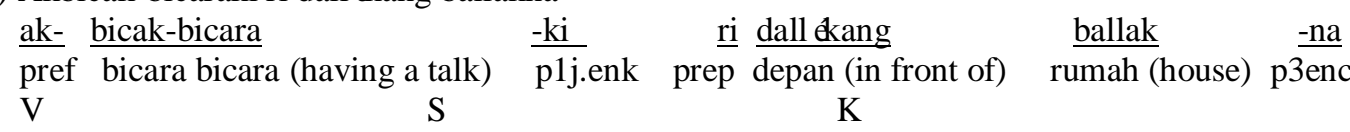

'Kita sedang bercakap-cakap di depan rumahnya'. ('We are having a talk in front of his house'.)

\section{B. Second Person Pronoun}

The second person pronoun is divided into the free and bound categories. Free person pronouns are in singular form and some are also plural. In addition, there is also a bound pronoun as the clitic, there are proclitic and enclitic.

\section{The Singular Second Person Pronoun}

The singular second-person pronoun has ' $k a u$ ' or 'engkau' the singular form of 'you' (familiar) and katté ' tuan / anda' (honorific). 'Kau' is spoken by the elder person who speaks to the younger, or by the person of a higher social status to the one of lower social status. It is also used when talking with friend or close relatives. These pronouns are in free form.

The free personal pronouns are generally preceded by article ' $i$ ' or 'si' as in 'ikau' (you), 'ikatté ' (you) (honorific) when it comes to the basic structure of a sentence. However, in some variants of the sentence structure, the article ' $i$ ' or ' $s i$ ' is omitted or undergoing an ellipsis. When it is not in the free form, the familiar singular second-person pronoun ' $i k a u$ ' is represented by enclitic ' $k o$ ', '- $n u$ ' and proclitic ' $n u$-'. Likewise, the honorific singular second-person pronoun 'ikatte' is represented by the enclitic ' $-k i$ ', '- $t a^{\prime}$ and the proclitic ' $k i-$ '. Enclitic $-k o$ (familiar) and '- $k i$ ' (honorific)', and proclitic ' $k i-$ ' (honorific) are attached to the verb functioning as the agentive role. Furthermore, enclitic $-n u$ (familiar) and - $t a$ (honorific) are attached to nouns as possessive marker. The familiar singular second-person pronoun is ' $i k a u$ ' and the honorific singular second-person pronoun is 'ikatte'.

1. The familiar singular Second Person Pronoun ikau

The familiar singular Second Person Pronoun ikau is always positioned at the beginning of the sentence.

Example: 
(15) Ikau mangé appilajarak

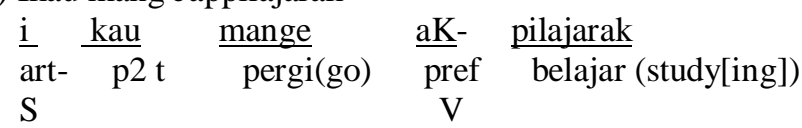

'Engkau pergi belajar.' (You go studying)

The honorific singular Second Person Pronoun ikatte

2. The honorific singular Second Person Pronoun ikatte is always positioned at the beginning of the Sentence.

Example:

(16) Ikatte mangé appilajarak

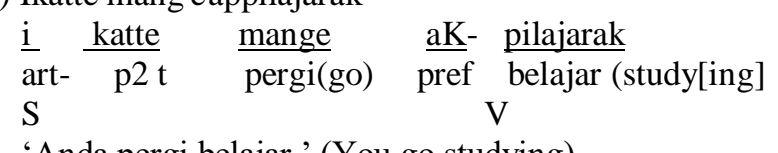

'Anda pergi belajar.' (You go studying)

In sentences (15) and (16), the personal pronoun 'ikaite' is positioned at the beginning of the sentence as the subject functioning as the agentive role. The sentence organization initiated by the personal pronoun 'ikatté' follows the SVO pattern.

3. Enclitic -ko and -ki

Enclitic -ko and -ki 'you' can be attached to the verb. Enclitic -ko' can be attached to the verb.

Example:

(17) Mangéko appilajarak.

mange $\quad \underline{-k o}$ aK- pilajarak

pergi(go) p2enc pref belajar(Study[ing])

$\mathrm{V} \quad \mathrm{S}$

'Pergi belajar engkau.' (You, go study)

Example:

Enclitic -ki can be attached behind a verb

(18) Mangéki appilajarak.

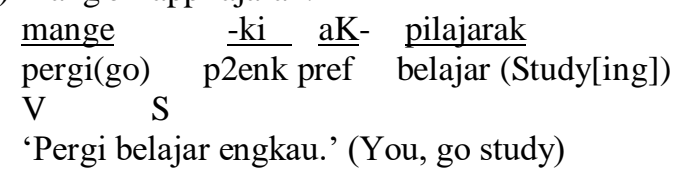

The enclitic ' $-k o$ ' in the sentence (17) and the enclitic ' $-k i$ ' in the sentence (18) are' attached at the end of the verb and occupy the subject function with an agentive role. These sentences follow the VSO pattern. The enclitic ' $-k o$ ' in the sentence (17) and the enclitic ' $-k i$ ' in sentence (18) form an imperative sentence. In certain situations, the enclitic ' $-k o$ ' and '- $k i$ ' is directly attached at the end of the verb of the act in which the speaker makes imperative.

Example:

(19) Appilajarakko

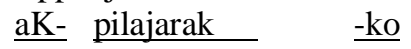

pref belajar(study) enc p2f

'Belajar engkau.' (You, study)

(20) Appilajarakki.

aK- pilajarak $-\mathrm{ki}$

pref belajar enc p2hon

'Belajar engkau.' (You, study)

\section{The Plural Second Person Pronouns}

In addition to the singular second-person pronoun, the Makassarese language also has the plural second-person pronoun. To distinguish it from the singular second-person pronouns, the speakers would add the morpheme 'ngaséng' as plural markers to 'kau' and 'katte'. Combining them makes 'kaungaséng' and 'katténgaséng'. The resulted combination 'kaungaseng' is the familiar form while katté ngaseng is honorific. That means, 'kaungaseng' is spoken by the elder to the younger, or by the person of a higher social status to the one of lower social status. It is also used to speak with friends and close relatives. These pronouns are in their free form.

The free personal pronoun is generally preceded by the article ' $i$ ' or 'si' as in 'ikaungaseng', or 'ikatténgaseng' when it comes to the basic structure of a sentence. However, in some variants of sentence structure, the article ' $i$ ' or ' $s i$ ' is omitted or undergoing an ellipsis. When there is not in the free form, the familiar plural second-person pronoun 'ikaungaseng' is represented by enclitic 'ngasengko -nungaseng' and proclitic 'nungaseng'. Likewise, the honorific plural second-person pronoun 'ikatténgaseng' are represented by the enclitic '-ngasengki' , '-tangaseng' and the proclitic 'ngasengki-'. Enclitic '-ngasengko' (familiar) and '-ngasengki' (honorific), and proclitic 'ngasengki'(honorific) are attached at the end of the verb functioning as the agentive role. Furthermore, enclitic '-nungaseng' (familiar), and '-tangaseng' (honorific) are attached to nouns as a possessive marker. 
Familiar Plural Second Person Pronouns ikaungaseng and Honorific Plural Second Person Pronouns ikattengaseng

- Familiar Plural Second Person Pronouns ikaungaseng

Familiar Plural Second Person Pronouns ikaungaseng is always located at the front of the sentence.

Example:

(21) Ikaungaseng mangé appilajarak

i kaungaseng mange aK-pilajarak

art- p2 j pergi(go) pref belajar(study[ing])

$\mathrm{S} \quad \mathrm{V}$

'Kalian pergi belajar' (You go studying)

- Honorific Plural Second Person Pronouns ikattengaseng

Honorific Plural Second Person Pronouns ikattengaseng is always located at the front of the sentence.

Example:

(22) Ikattengaseng mangé appilajarak

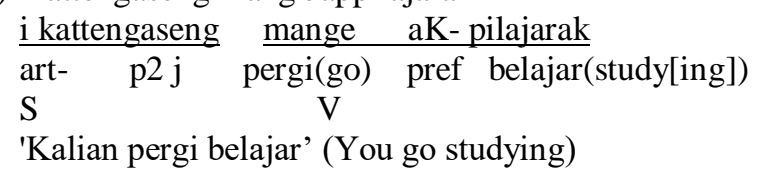

The familiar plural second-person pronouns 'ikaungaseng' and the honorific plural second-person pronouns in the sentence (21) and (22) are positioned at the beginning of the sentence as the subject with an agentive role. Those sentences follow the SVO pattern.

4. Enclitic -ngasengko and -ngasengki

Enclitic -ngasengko and -ngasengki can be attached to the verb. Enclitic -ngasengko can be attached to the verb. Example:

(23) Mangéngasengko appilajarak!

mange $\underline{\text {-ngasengko aK- pilajarak }}$

pergi(go) p2enk pref belajar(study[ing])

$\mathrm{V} \quad \mathrm{S}$

'Pergi belajar kalian!' (You all,/ You folks, go studying!)

5. Enklitika -ngasengki can be attached behind the verb

Example:

(24) Mangéngasengki appilajarak!

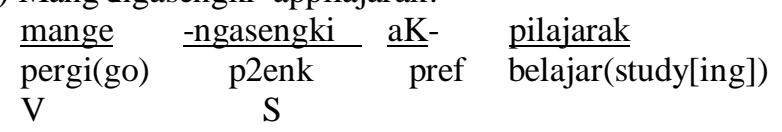

'Pergi belajar kalian!' (You all,/ You folks, go studying!)

The enclitic '-ngasengko' in sentence (23) and '-ngasengki' in the sentence (24) are attached at the end of the verb and occupies the function of subject with an agentive role. These sentences follow the VSO pattern. The enclitic 'ngasengko' in sentence (23) and the enclitic ' $-k i$ ' in the sentence (24) form an imperative sentence. In certain situations, the enclitic '-ngasengko' and '-ngasengki' are directly attached at the end of the verb of the act in which the speaker makes an imperative.

Example:

(25) Appilajarakngasengko!

$\frac{\text { aK- }}{\text { pref }}$ belajarar(study) $\frac{\text {-ngasengko }}{\text { enc p2jf }}$
'Belajar kalian!' (study, you all/you folks!)
Appilajarakngasengki!
$\frac{\text { aK- }}{\text { pref }}$ belajarak
'Belajar kalian!' (study, you all/you folks!)

\section{Third Person Pronoun}

The third person pronoun is divided into free personal pronouns and bound personal pronoun categories. Free personal pronouns can be singular or plural. In addition, there is also a bound pronoun as the clitic: proclitic and enclitic.

The Singular Third Person Pronouns

The singular third-person pronouns ' $i a$ ' (she/he) occupies the subject function or complement.

Example:

$$
\begin{aligned}
& \text { (26) Ia angkiringi ak doek }
\end{aligned}
$$

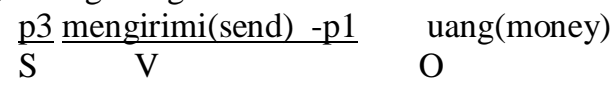

$$
\begin{aligned}
& \text { 'Ia mengirimi saya uang.'(She/he send me money) }
\end{aligned}
$$


The singular third-person pronoun ' $i a$ ' (she/he) at the beginning of a sentence serves as a subject with the agentive role. The sentence follows the SVO pattern. ' $I a$ ' also serves as an object which acts as a topic of the sentence.
(27) Akkiring ak doék Mengirimi(send) -p1 uang(money)
$\mathrm{V} \quad \mathrm{S}$ O
mange ri ia
prep p1\
Comp
'Saya mengirimi dia uang.' (I send money to him) $\underline{\text { Uang(money) p1- kirim(send) prep p3 }}$
S V Komp
'Uang saya kirim kepadanya. (I send money to him)
(28) Doek ku kiring mangé ri ia.

If a sentence gets mutated, some personal elements undergo ellipsis and some others do not. When a sentence does not undergo ellipsis in any of its elements, its semantic meaning is still endured. The personal element subjected to ellipsis can be traced by observing the verb that follows the elements in question. The overhaul is based on whether the verb is a transitive verb or an intransitive verb or based on the category of the verb phrase that follows the predicate function of the sentence. The transitivity or intransitivity of a verb that follows a personal pronoun as the subject's filler does not significantly affect the clarity of the personal element in the sentence.

Example:

(29) Ia anngallé
p3-mengambil(take/took)
$\mathrm{S} \mathrm{V}$ jéknék ri banngia
'Dia mengambil air pada malam itu.'(He/she took the water that night).
(30) anngallé i jéknék ri banngia
$\frac{\text { mengambil-p3 }}{\mathrm{V} \quad \mathrm{S} \quad \mathrm{O}} \mathrm{K}$ pada malam-def
'Mengambil air dia pada malam itu.' (He/she took the water that night)
(31) Jéknék na allé
$\frac{\mathrm{air} \text { p3- diambil }}{\mathrm{S}} \mathrm{\text {padamalam-def }}$
'Air dia ambil pada malam itu.' (He/she took the water that night)

Sentences (29) and (30) are transitive sentences because there are nouns that serve as objects following the V. It is shown by the verb 'anngallé (take) that is followed by noun 'jeknek' (water). However, the three sentences above have pronouns going through ellipsis. Initially, in the sentence (29), ' $i a^{\prime}$ is put in front of the sentence serving as $\mathrm{S}$ then gets omitted in the sentence (30) as it is replaced by the absolutive marker ' $-i$ ' at the end of the verb referring to the same person. As for the sentence (31), the pronoun is transformed into proclitic ' $n a$ - ' in front of the verb, the noun 'jéknék' (water) is put at the beginning of the sentence.

The personal pronoun ' $n a-$ ' always precedes the verb with an agentive role. Whereas ' $n a$ ' is attached at the end of the word it clings to. The ' $-n a$ ' acts as a possessive marker as in 'sapedana' (his/her bike).

Example:

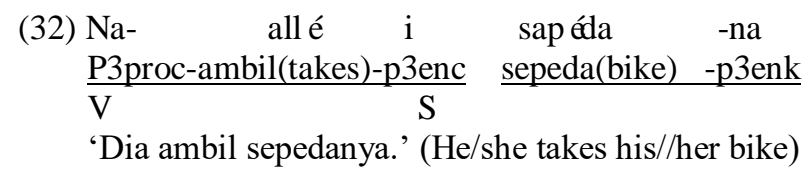

The third person pronoun in Makassarese language is the singular ' $i a$ ', the plural 'iangaséng'. Both forms may occupy the subject of complement function. The personal pronoun ' $i a$ ' at the beginning of the sentence is assumed as the agentive role. This type of pronoun organization follows the SVO pattern.

Example:

(33) Ia $\quad$ a ngkiringi ak $\quad$ doek
p3
$\begin{aligned} & \text { mengirimi(send)-p1 } \\ & \text { 'Ia mengirimi saya uang.' (She/he send me money) }\end{aligned}$
Ia may also function as an object and act as the topic of the sentence.

Example:

(34) Akkiringak doék mange ri ia
Mengirimi(send)-p1 uang prep p1
'Saya mengirimi dia uang.' (I send him/her money)
(35) Doek ku kiring mangé ri ia.
Uang(money) p1- kirim prep p3
S V Comp


If a sentence gets mutated, some personal elements undergo ellipsis and some others do not. When a sentence does not undergo ellipsis in any of its elements, its semantic meaning does not also undergo any change. The personal element subjected to ellipsis can be traced by observing the verb that follows the elements in question. It is done by seeing whether the verb is a transitive verb or an intransitive verb or based on the category of the verb phrase that follows the predicate function of the sentence. The transitivity or intransitivity of a verb following a personal pronoun does not significantly affect the clarity of the personal element in the sentence.

Example:

(36) Ia anngallé jéknék ri banngia

$\frac{\text { p3-mengambil }}{\mathrm{V}} \frac{\text { air }}{\mathrm{O}} \frac{\text { pada malam-def }}{\mathrm{K}}$

'Dia mengambil air pada malam itu.' (He/she took the water that night)

(37) Anngalléi jéknék ri banngia

$\underline{\text { mengambil-p3 }}$ air pada malam-def

$\mathrm{V} \mathrm{S} \quad \mathrm{O}-\mathrm{K}$

'Mengambil air dia pada malam itu.' (He/she took the water that night)

(38) Jéknék naallé ri banngia

$\frac{\text { air }}{\mathrm{S}} \frac{\text { 3-diambil }}{\mathrm{V}} \frac{\text { pada malam-def }}{\mathrm{O}}$

'Air dia ambil pada malam itu.' (He/she took the water that night)

Sentences (36) and (37) are transitive sentences because nouns are serving as objects after the V. It is shown by the verb 'anngallé (take) that is followed by the noun 'jeknek' (water). However, the three sentences above have pronouns going through ellipsis. Initially, in the sentence (39), ' $i \mathrm{a}^{\prime}$ is put in front of the sentence serving as $\mathrm{S}$ then gets omitted in a sentence (30) that it is replaced by the absolutive marker ' $-i$ ' at the end of the verb referring to the same person. As for the sentence (38), the pronoun is transformed into proclitic 'na- ' in front of the verb, the noun 'jéknék' (water) is put at the beginning of the sentence.

The personal pronoun ' $n a$ - ' always precedes the verb with an agentive role. Whereas, the ' $-n a$ ' is attached at the end of the word it clings to. The '-na' acts as a possessive marker as in 'sapedana' (his/her bike).

Example :

$$
\begin{array}{lll}
\text { (39) } \mathrm{Na} & \text { allé } \mathrm{i} & \text { sapéda na } \\
\text { P3prok- } & \text { ambil-p3enk } & \text { sepeda-p3enk } \\
\mathrm{V} & \mathrm{S} & \\
\text { 'Dia ambil sepedanya.' (He/She takes the bike) }
\end{array}
$$

\section{CONCLUSION}

Makassar language is a language with unique characteristics. If it is associated with the elements that build it, one word suggests the meaning to the containing sentence (grammatical). The personal pronoun is required to form a sentence such as free pronoun and bound pronoun which is the clitic. Clitic is divided into two: proclitic and enclitic. The clitic attached in front of the verb is called proclitic and the clitic attached at the end of the verb is called enclitic. A sentence that begins with verbs clung by enclitic forms a sentence structure of VS pattern. The sentence that begins with free pronoun forms the sentence structure of the SV pattern of a variety of structures. Thus, the basic pattern of the Makassarese sentence is the VS that accentuates the event, whereas the SV pattern with its many structural variations is considered derivation or modification/transformation resulted from basic sentences.

\section{REFERENCES}

[1] Abbas, Asriani. (2014). Perilaku Morfosintaksis Verba Bahasa Makassar. Disertasi. Pascasarjana Universitas Hasanuddin, Makassar.

[2] Basang dan Arif. (1981). Struktur Bahasa Makassar. Jakarta: Pembinaan dan Pengembangan Bahasa.

[3] Comrie, B. (1978). Ergativity. Syntactic Typology: Studies in Phenomenology of Language. Lehmann (ed.). Texas: University of Texas Press.

[4] Dixon. (1994). Ergativity. Cambridge: Cambridge University Press.

[5] Haruna, Muhammad Jafar. (1996). Pronomina Persona Bahasa Makassar: Satu Pendekatan Teori Jejak. Disertasi. Program Pascasarjana Universitas Padjajaran, Bandung.

[6] Hasyim, M. (2017). The metaphor of consumerism. Journal of Language Teaching and Research, 8(3), 523-530.

[7] Hasyim, M., Saleh, F., Yusuf, R., Abbas, A. (2021). Artificial Intelligence: Machine Translation Accuracy in Translating French-Indonesian Culinary Texts. International Journal of Advanced Computer Science and Applications, 12(3), 186-191.

[8] Ibrahim, A.G. (2002). Keergatifan dan Ketransitifan dalam Wacana Bahasa Tae'. Disertasi. Program Pascasarjana Universitas Hasanuddin, Makassar.

[9] Karim, K., Maknun, T., Abbas, A. (2019). Praanggapan Dalam Pamflet Sosialisasi Pelestarian Lingkungan di Kabupaten Wakatobi. Jurnal Ilmu Budaya, 7 (2), 241-247.

[10] Kaseng, S. (1982). Bahasa Bugis Soppeng Valensi Morfologi Dasar Kata. Jakarta: Jambatan. 
[11] Lehmann, W.P. (ed.). (1978). Syntactic Typology, Studies in the Phenomenology of Language. Hassocks: The Harvester Press Limited.

[12] Palenkahu, R.A., dkk. (1974). Peta Bahasa Sulawesi Selatan. Makassar: Lembaga Bahasa Nasional Cabang III.

[13] Payne. (1997). Describing Morphosyntax: A Guide for Field Linguists. Cambridge: Cambridge University Press.

[14] Rahman, F., Abbas, A., Hasyim, M. (2019). Facebook Group as Media of Learning Writing in ESP Context: A Case Study at Hasanuddin University. Asian EFL Journal Research Articles, 26 (6.1), 153-167

[15] Ramlan, M. (1985). Tata Bahasa Indonesia Penggolongan Kata. Yogyakarta: Andi Offset.

[16] Taufik. T., Maknun, T., Abbas, A. (2017). Deiksis Persona Bahasa Indonesia Dialek Ambon. Jurnal Ilmu Budaya, 5 (2), $23-31$.

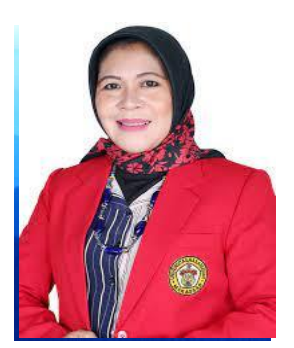

Asriani Abbas is a lecturer at the Indonesian Literature Study Program, Faculty of Cultural Sciences, Hasanuddin University. He completed his doctoral studies in linguistics at Hasanuddin University. He has done a lot of research in the field of Indonesian linguistics and comparative studies of regional languages

Kaharuddin is an assistant professor in the field of linguistics and Indonesian language at the Indonesian Literature study program, Faculty of Cultural Sciences, Hasanuddin University. He does a lot of research on languages and comparative studies of regional languages with Indonesian

Muhammad Hasyim is a professor in the field of linguistics (semiotic studies). He is a lecturer at the French Literature Study Program, Faculty of Cultural Sciences, Hasanuddin University. He completed his doctoral study in linguistics at Hasanuddin University with his dissertation research in semiotics. He has done a lot of research in language, culture and media studies with a semiotic approach. 